\title{
Socio-Economic Implications of Private Participation in the Provision of University Education in Nigeria
}

\author{
Joseph Babatola Ayodele \\ Department of Educational Foundations and Management, Faculty of Education, \\ University of Ado-Ekiti, Ado-Ekiti, Nigeria \\ tolayodele@yahoo.co.uk
}

\begin{abstract}
This paper examines the socio-economic implications of private participation in the provision of university education in Nigeria. This is with a view to providing information that will guide the Nigerian government on its public-private partnership (PPP) policy as it affects the education enterprise. The study was descriptive and carried out Ex-post-Facto. Data was collected from randomly selected university students on the income level of their parents and their expenditure at school per session. Findings from data analysis showed that students spend more in state universities than in federal universities. In addition, students spend more in private universities than in public universities. Findings also showed that parents of students in pubic universities earn relatively less income but pay relatively more for university education. In view of the implications of these findings, it is recommended that the Nigerian government should establish a contributory Education Savings Scheme in addition to a functional Education Loans Scheme. Special Scholarship schemes should also be introduced for indigent but brilliant university students. The Nigerian government should also formulate and implement people-oriented policies that will reduce widespread poverty. Selective-user charges should also be introduced to make the wealthy pay more for university education.
\end{abstract}

\section{Introduction}

A higher level of education is a sine qua-non for upward social and economic mobility in recent times. Direct private investment in higher education has been embarked upon in order to enjoy gains resulting from it in the form of increased earnings. Higher education has the effect of further stratifying individuals by stage of performance, rather than equalizing opportunity [6].

The education-manpower link underscores the view that investment in human beings (in terms of improved skills, positive attitude, and enhanced competence) will increase production levels and thus hasten the process of economic growth. In other words, the higher the level of education, the higher the productivity. This implies that investment in university education increases the production capacity of individual citizens and subsequently increases the Gross Domestic Product (GDP).

The economic recession which began in the Western world after the oil price shock in the mid1970s spread like wildfire throughout most developing countries in the late 1970s and early 1980s. Thus a new crisis became manifest in the early 1980s culminating in the balance of payments and budget deficits. This severely affected the resource-base of governments to adequately finance the education enterprise. New problems thus emerged as consequences of the recession and of political and economic responses to it.

Nigeria is not an exemption in terms of the problems and imbalances that were rooted in the economic and thus the educational system [3]. The observed crisis on educational priorities coupled with observed waste in public enterprise might have therefore, called for policy reforms since the late 1980s in Nigeria.

In the 1980s, the hydra-headed Structural Adjustment Programme (SAP) was offered to Nigeria and indeed other African countries as a programme of economic recovery. The necessary adjustment or reforms which involves 'downsizing', liberalisation of trade, 'marketisation' (commercialization), privatisation and reduction of social spending are the usual ingredients of neo-liberalism capitalism [10].

In recent times, more private participation in virtually all sectors of the Nigerian economy is being embraced. This is in line with the global trend of Public-Private Partnership (PPP) in financing public enterprises. The underlying assumption was that the public sector has not been efficient and there was the need to give the private sector to power the economy.

Private participation in the provision of educational services is also an offshoot of decentralised (or deregulation) of education. Decentralisation of education is not peculiar to Nigeria. In the 1950s, for example, the Chinese government adopted the combination of regular government funded education and the community-run schools with government subsidy [4]. The emergence of private schools during this wave of decentralisation of public education provided a convenient rationale for the acceptance of private schooling under market mechanisms [7].

Access to university education in recent times is also a function of affordability, in addition to the carrying capacity of the universities as determined by 
the National Universities Commission (NUC). There is no doubt that there is increasing incidence of poverty at the household level in Nigeria. About 70\% Nigerians are poor and thus cannot afford to send their children/wards to school. This is because only $30 \%$ of families can afford to live with US $\$ 1$ or above daily [9]. The World Bank uses reference lines set at US\$1 per day as benchmark to measure extreme poverty. This implies that over $70 \%$ Nigerians live below extreme poverty line [13]. In addition, 92\% of Nigeria's population lives on less than US\$2 per day. This implies that 92\% Nigerians live below poverty line (of US\$2 per day) [13]. Private universities in Nigeria are only able to enroll less than 150 students, instead of their quota of 500, per annum. In addition, the number of students per university is 6,000. This is, however, overwhelmingly skewed in favour of the federal, and to a lesser degree state universities, where student enrolment per university is over 20,000. The determining factor is the issue of fees in private universities, where the fee structure ranges between \$300,000 (US\$2,000) and over \$1,000,000 (US\$6,666.7) per annum [1].

The question then arises that, 'What are the socio-economic implications of private participation in the provision of university education in Nigeria?' It is against this background that this paper examines the historical antecedent of decentralisation of education in Nigeria. The paper also traces the trend in the growth of university education since independence in 1960. In addition, the paper investigates the socio-economic implications of private participation in the provision of university education in Nigeria by comparing the proportionate share of household income spent on university education services with the average household income and also with the per capita GDP.

It is expected that the research would provide the needed information on the impact of the implementation government's policy of privatisation of the education enterprise. In addition, education policy makers could be better guided by the study while taking decisions on bursary and scholarship schemes.

\section{Decentralisation of Education in Nigeria: Historical Antecedent}

The early years of western education in Nigeria will serve as a veritable guide to examine the trend in the proprietorship and control of educational institutions in Nigeria. The development in school ownership and control could be considered under four non-mutually exclusive periods [8]. These are:

- Missionary monopoly and control era (18841904): This period was characterised by complete ownership and control of schools by religious or church groups, which took the initiative in different parts of the country, at different times.

- Dual ownership and control era (1904-1970): This period was an offshoot of the 1887 Education Code, which led to the existence of government and voluntary agency schools operating simultaneously.

- Government dominance and take-over of schools era (1970-1985): Government dominance and complete takeover of schools was formalised by the 'School Take-Over Validation Decree' No. 41 of 1977.

- Return of mission schools/partnership era (1985-Date): The deplorable infrastructural state of public schools coupled with apparent dwindling quality of instruction ignited a loss of confidence by parents in the public schools. There was thus intense pressure on the government to allow parents and students to have some choice in laying a solid foundation for their future through virile education enterprise. In the 1980s, the government succumbed to pressures to allow private schools to exist side-by-side with public schools. Perhaps, it is in line with this understanding that private educational institutions have been on the increase to complement government efforts, as provided for in the National Policy on Education [11].

\section{Historical Development of University Education in Nigeria}

The development and subsequent expansion of university education in Nigeria can be traced to the nationalist struggle for political emancipation and self-determination in the first half of the $20^{\text {th }}$ century. The University College Ibadan was established in January 1948 on the basis of the recommendations of the Elliot Commission set up in 1943. The foundation for future expansion was further laid by the report of the Ashby Commission set up at the eve of independence in 1959. The report identified poor manpower situation in the country and thus the need for more higher education institutions. The recommendation of the Commission ushered in growth of universities both in numbers and in student enrolment during the post-independence period [12]. It is noteworthy that the number of universities in Nigeria has increased from 2 at independence in 1960 to 117 in 2011.

The emergence of private universities in Nigeria has added to the number of universities in the country. The foundation of private participation in the provision of university education was laid in 1979 when education was placed on the concurrent list in Nigeria's constitution. The constitution made provision for individuals, private entrepreneurs and organisations to establish and operate private institutions alongside with the federal and state governments. The licensing of private universities 
started in 1999 with three private universities. At present (May 2011), forty-five (45) private universities have been approved by the NUC and they are fully in operation. This number constitutes about $40 \%$ of the total number of universities in Nigeria (117).

Apart from the constitutional provisions, several reasons may also be advanced for the emergence and growth of private universities in Nigeria. These include inadequate learning/educational resources in public universities; loss of confidence by parents/guardians and students in public universities due to insecurity, cultism, incessant industrial actions, etc. The need to expand access to match increasing local demand for university education and to align with the practices in developed countries where both private and public sectors are involved in the provision and management of university education, have equally led to the increase in private universities in recent times [2][5].

\section{Method}

The study was descriptive and it was carried out Ex-post Facto. Data was collected from randomly selected university undergraduates on the income level and social status of their parent(s) as well as their expenditure at school per session. Descriptive statistical tool was used to analyse the data in order to make realistic conclusion that could guide policy decisions.

\section{Results and Discussion}

The findings from the analysis of data are presented in Table 1.

Table 1. Household income, household expenditure on university education and per capita GDP in

Nigeria

\begin{tabular}{|c|c|c|c|c|c|}
\hline \multicolumn{2}{|c|}{$\begin{array}{c}\text { Ownership of } \\
\text { university }\end{array}$} & $\begin{array}{c}\text { Average } \\
\text { househol } \\
\text { d income } \\
\text { (AHI) } \\
\text { US\$ }\end{array}$ & $\begin{array}{c}\text { Average } \\
\text { household } \\
\text { expenditur } \\
\text { e on } \\
\text { university } \\
\text { education } \\
\text { (AHEU) } \\
\text { US\$ }\end{array}$ & $\begin{array}{c}\text { AHE } \\
\text { U as } \\
\text { perce } \\
\text { ntage } \\
\text { of } \\
\text { AHI } \\
\%\end{array}$ & $\begin{array}{c}{ }^{*} G D P \\
\text { per } \\
\text { capita } \\
\text { US\$ }\end{array}$ \\
\hline \multirow{3}{*}{ Public } & State & $5,267.70$ & 937.73 & 17.8 & \multirow{5}{*}{1,140} \\
\hline & $\begin{array}{c}\text { Feder } \\
\text { al }\end{array}$ & 12,199 & 509 & 4.2 & \\
\hline & $\begin{array}{c}\text { All } \\
\text { Public }\end{array}$ & $7,520.95$ & 796.95 & 10.6 & \\
\hline \multicolumn{2}{|c|}{ Private } & 104,468 & 4,610 & 22.7 & \\
\hline \multicolumn{2}{|c|}{ Public \& Private } & $7,025.95$ & $1,295.33$ & 18.4 & \\
\hline
\end{tabular}

Table 1 shows the proportionate share of average household expenditure on university education (AHEU) as a percentage of average household income (AHI) and the GDP per capita as at December, 2010.

The following can be deduced from the table:

i. AHEU in federal universities (US\$509) is less than AHEU in state universities (US\$937.73).

ii. AHI of parents of students in federal universities (US\$12,199) is greater than AHI of parents of students in state universities.

iii. In private universities, AHEU constitutes 22.7\% of AHI, while in public universities, AHEU constitutes $10.6 \%$ of AHI.

iv. AHEU in private universities (US\$4,610) is higher than AHEU in public universities (US\$996.95).

v. AHI of parents of students in private universities (US\$104,468) is greater than the AHI of parents of students in public universities (US\$7,520.95).

vi. While AHEU constitutes $17.8 \%$ of $\mathrm{AHI}$ in state universities, it constitutes $4.2 \%$ in federal universities. Thus, parents of students in federal universities earn relatively more income, but pay relatively less for university education.

vii. While AHI of parents of children in public universities is $7 \%$ of that of parents of children in private universities, the AHEU in public universities is $17 \%$ of that for private universities. Thus, parents of students in public universities earn relatively less income but pay relatively more for university education.

viii. The per capita GDP (GDPPc) is less than AHI of parents of children in Nigerian universities.

ix. The GDDPc is greater than AHEU in Nigeria.

\section{Socio-Economic Implications}

The implication of the findings cannot be overemphasised. While the current trend in licensing private universities in Nigeria might be premised on the pursuit of social efficiency, it not only reflects the intensification of social inequality, it also serves the interest of the wealthy parents rather than the public [4]. In addition, while the Nigerian government felt that decentralisation of education is worthwhile and most desirable in line with the PPP argument and in the face of dwindling national resources and global economic crisis, the goal of enhancing access to university education through licensing of private universities has been aborted since these elitist institutions have metamorphosed into profit-making ventures [12]. The exorbitant fees are not affordable by vast majority of Nigerians.

Findings from data analysis showed that AHI>GDPPc. One may wish to conclude that parents should be able to afford the increasing cost of university education. It should be noted here that the AHI is not solely spent on university education. There are other items of household expenditure 
which may not even be adequately met by the AHI of Nigerians with large family size. There is also higher income inequality in Nigeria which is highly skewed against the majority of Nigerians who live below abject poverty line [13].

\section{Conclusion}

Decentralisation of university education in Nigeria involves a blending of private and public participation in the provision of education services. It also operates within the framework of privatisation which involves a shift from public provision of higher education to widespread private ownership and control of university education. The socioeconomic implications of this policy are obvious. It makes university education expensive and thus reduces in-take because of the expenses involved. High fee paying (private) universities are thus affordable only by the rich. More importantly, access to the public universities, although with relatively low fees compared with private universities, is limited due to widespread poverty of Nigerians. Thus, privatisation of university education could disproportionately affect low-income families and tends to widen the existing gap between the rich and the poor.

\section{Recommendations}

In view of the far-reaching socio-economic implications of private participation in the provision of university education, the following recommendations are considered worthwhile. The government should put in place realistic measures to increase citizens' income generating capacity with a view to reducing widespread household poverty. The government should also introduce contributory Education Savings Scheme to encourage parents to save for their children's university education. In the same vein, there should be the establishment of Special Scholarship Scheme for indigent, but brilliant university students. The government at all levels should as a matter of urgency increase the beneficiaries of bursary awards as well as increase the amount of bursary to be in line with economic realities and increases in fees payable by university students. Selective user-charges could also be introduced to make the wealthy parents pay more for university education. Functional Education Loans Scheme should also be introduced for university students to be utilised for payment of fees, procurement of educational equipment and to meet the cost of additional living expenses during the period of study. The mode of payback should be flexible and realistic.

\section{References}

[1] Adedipe, N. O. (2010). Challenges of access to university education in Nigeria. The Nation on Sunday, October 31: 52.

[2] Ajayi, I. A. \& Ekundayo, H. T., (2010). Contemporary issues in educational management. Lagos: Bolabay Publications.

[3] Ayodele, J. B. \& Ayeni, M. A., (2006). Deregulation of education in Nigeria: Implications for quality control. Nigerian Journal of Educational Philosophy. 1(2): 43-50.

[4] Cheng, H. \& DeLany, B., (2002). Quality education and social stratification: The paradox of private schooling in China. Current Issues in Comparative Education. 1(2): 48-56. Teachers College, Columbia University.

[5] Chukwuma, R. A. \& Nwaham, C. O., (2007). Establishment and management of private universities in Nigeria: The trend, problems and challenges. In J. B. Babalola, G. O. Akpa, A. O. Ayeni \& S. O. Adedeji (eds). Access, equity and quality in higher education. NAEAP. 99-108.

[6] Commons, M. L., (2008). Implications of hierarchical complexity for social stratification, economics and education. World Futures. 64: 430435.

[7] DeLany, B., (1997). Education in the Chinese marketplace: Decentralisation, privatisation and changing norms of equity in Chinese education. Paper presented at the Conference of China toward $21^{\text {st }}$ Century. Hong Kong. August 13-21.

[8] Education Sector Analysis, (2003). Historical background on the development of education in Nigeria. Abuja: Education Sector Analysis.

[9] Ehiametalor, E. T., (2005). Issues of access, equity and private sector participation in the deregulation of education. In G. O. Akpa, S. U. Udoh \& E. O. Fagbamiye (eds). Deregulating the provision and management of education in Nigeria. NAEAP. Jos: MPGINAC Concept Ltd.

[10] Fashina, D., (2001). Nigerian tertiary education system: What future? A keynote address. In S. Jegede, A. Ale \& E. Akinsola (eds). Nigeria's tertiary institutions and human rights. Ikeja, Lagos: CDHR. 
[11] Federal Republic of Nigeria, (2004). National Policy on Education (Revised). Lagos: NERDC.

[12] Seweje, R. O. \& Ayodele, J. B., (2010). Access to university education in Nigeria. In F. Omotoso, A. A. Agagu \& O. Abegunde (eds). Governance, politics and policies in Nigeria: An essay in honour of Prof. Dipo Kolawole. Chapter 24: 323-335. Porto Novo, Benin Republic: ESAF.

[13] USAID and Population Reference Bureau, (2009). Population and economic development linkages. 2007 data sheet. Washington DC: USAID/PRB.

[14] World Bank, (2010). World development indicators database. Washington DC: World Bank. 